\title{
Traditional Varieties of Caupi Submitted to Water Deficit: Physiological and Biochemical Aspects
}

\author{
Bruno do Nascimento Silva ${ }^{1}$, Stelamaris de Oliveira Paula ${ }^{2}$, Joniele Vieira de Oliveira ${ }^{1}$, Johny de Souza Silva ${ }^{3}$, \\ Cândida Hermínia Campos de Magalhães ${ }^{3}$, Enéas Gomes-Filho ${ }^{2}$ \& Rosilene Oliveira Mesquita ${ }^{3}$ \\ ${ }^{1}$ Agronomist, Agrarian Sciences Center, Federal University of Ceará, Fortaleza, Ceará, Brazil \\ ${ }^{2}$ Department of Biochemistry and Molecular Biology, Science Center, Federal University of Ceará, Fortaleza, \\ Ceará, Brazil \\ ${ }^{3}$ Department of Fitotecnia, Agrarian Sciences Center, Federal University of Ceará, Fortaleza, Ceará, Brazil \\ Correspondence: Rosilene Oliveira Mesquita, Department of Fitotecnia, Agrarian Sciences Center, Federal \\ University of Ceará, Fortaleza, Ceará, Brazil. E-mail: rosilenemesquita@ufc.br
}

Received: February 17, 2019

Accepted: March 21, $2019 \quad$ Online Published: May 15, 2019

doi:10.5539/jas.v11n6p424

URL: https://doi.org/10.5539/jas.v11n6p424

\begin{abstract}
The cowpea (Vigna unguiculata (L.) Walp) it is a leguminous widely cultivated in Northeast of Brazil. In the state of Ceara, its cultivation is performed mainly by family farms who make use of traditional varieties of good adaptation to the growing region. Thus, characterizing traditional varieties with characteristics of adaptation to regions with water shortage is essential for the production of food in the world, especially in semi-arid regions. In this sense, the objective was to evaluate the physiological and biochemical responses in three genotypes of cowpea, being two traditional varieties grown in Ceara (Sempre-Verde and Cabeça-de-Gato) and a genotype characterized as a standard of drought tolerance (Pingo-de-Ouro-1,2) under three water regimes: irrigated, moderate deficit and severe water deficit. The parameters evaluated were: gas exchange, chlorophyll $a$ fluorescence, photosynthetic pigments, organic solutes (proline, total carbohydrates, reducing and non-reducing carbohydrates), starch and enzyme activity (APX, G-POD, CAT and SOD). The genotype Pingo-de-Ouro-1,2 confirmed its tolerance pattern in a water deficit condition, presenting greater water potential, higher photosynthetic rate, high levels of total carbohydrates and high accumulation of proline. Among the traditional varieties, the Cabeça-de-Gato presented superior photosynthesis to Sempre-Verde higher Electron Transport Rate (ETR), reflecting in a greater photochemical quenching $(\mathrm{qP})$ and a greater accumulation of proline, indicating that this variety presents more pronounced adaptive characteristics for water restriction conditions, which is a common condition to the Brazilian semiarid.
\end{abstract}

Keywords: osmotic adjustment, chlorophyll fluorescence, biochemistry, drought tolerance, gas exchange, Vigna unguiculata (L.) Walp

\section{Introduction}

The cowpea (Vigna unguiculata (L.) Walp.) is a legume originating in West Africa, having great nutritional and economic importance where it is cultivated, such as the semi-arid tropics, Asia, Africa, south-east Europe, and Central and South America. Its cultivation is justified by its development and productive capacity in areas where other crops do not produce satisfactorily, due to high temperatures and irregular rains (Akibode \& Maredia, 2011). In Brazil, its cultivation is of great importance in the North and Northeast, with increasing progress in the Central-West region (Rocha et al., 2009).

Plants generally acclimate or adapt to environments with limitations, involving various protection mechanisms, such as, morphological, physiological, biochemical and molecular. Water is considered the most important and limiting resource for growth and crop productivity, making its restriction one of the most prejudicial abiotic stresses in relation to ability, survival and yield of crops (Pinheiro \& Chaves, 2011; Simova-Stoilova et al., 2015; Gagné-Bourque et al., 2016). To deal with these water restriction conditions the plants developed, over time, a variety of adaptive strategies, based on the concepts of escape, avoidance and tolerance (Goufo et al., 2017). An example would be the development of mechanisms of control at the physiological level, such as, regulation of stomatal opening, directly affecting the perspiration and $\mathrm{CO}_{2}$ assimilation (Alderfasi et al., 2017; Sicher, Timlin, 
\& Bailey, 2012), modulation of gas exchange and alterations to biochemical level simultaneously (Goufo et al., 2017; Rivas et al., 2016), in addition to morphological changes such as the development of deeper roots (Araus et al., 2002), decrease of the growth rate and reduction of leaf area (Cardona-Ayala et al., 2013). At the biochemical level, plants that present a standard tolerance to water deficit seek the maintenance of tissue turgidity through osmotic adjustment, through the accumulation of inorganic or organic solutes, being that the synthesis and/or accumulation of these solutes will depend on the water status of the plant and the genotype (Blum, 2017; Rivas et al., 2016).

The role of osmoprotection in cowpea is not well established and presents divergences between the different genotypes. In some cultivars under water stress, rapid and significant changes in proline levels are observed, favoring osmotic adjustment (Hamidou, Zombre, \& Braconnier, 2007; Costa et al., 2011). In other cultivars, proline does not accumulate or only increases after several days of the imposition of the water deficit (Singh \& Reddy, 2011; Shui et al., 2013). This delayed response may be linked to the protection of the photosynthetic apparatus (Goufo et al., 2017), once this solute acts on the reduction of NADPH from glutamate (proline precursor), thus avoiding the generation of singlet oxygen (Cecchini et al., 2011). In addition to proline, other organic solutes may be directly involved in osmotic adjustment and may contribute of differential form in tolerance to water stress in cowpea.

Due to these variations between rapid and late responses, the physiological and biochemical changes in cowpea in a water deficiency condition are not yet fully understood. However, these late responses can be more specific and can be directly related to the mechanisms induced by the diffusive and biochemical limitations of photosynthesis in order to protect the photosynthetic apparatus against excess reactive oxygen species. In general, atmospheric $\mathrm{CO}_{2}$ diffuses through the stomata into the intercellular spaces and then through the mesophyll to the carboxylation sites. The limitations to the assimilation of $\mathrm{CO}_{2}$ imposed by the stomatal closure in the leaves during the water stress can lead to an imbalance between the generation of electrons in photosystem II (PSII) and the electron requirement for photosynthesis. In turn, this could lead to hyperexcitation and subsequent photoinhibitory damage of the PSII reaction centers from the mesophyll and the biochemical limitations of photosynthesis.

All this divergence between the answers, resulting from the great genetic diversity of the cowpea, is the object of study by many researchers who seek to elucidate the interaction between the physiological and biochemical processes to deal with drought and to identify promising genotypes (Singh \& Reedy, 2011). The objective of this work was to study the effects of water stress on physiological and biochemical responses in three genotypes of cowpea with differences and responses that are important for the Brazilian semi-arid region.

\section{Methodology}

\subsection{Plant Material, Growing Conditions and Experimental Design}

The experiment was conducted in a greenhouse belonging to the Federal University of Ceara (UFC), in Fortaleza, from June to August 2016, where the flux density of photosynthesizing photons at noon was approximately $1.300 \mathrm{~mol} \mathrm{~m}^{-2} \mathrm{~s}^{-1}$ and average temperature of $32.0 \pm 2{ }^{\circ} \mathrm{C}$. Three genotypes were used, two traditional varieties being collected in the state of Ceará/Brazil: Sempre-Verde (from Tururu-CE/Brazil) and Cabeça-de-Gato (originally from Juazeiro do Norte-CE/Brazil); and the standard genotype for drought tolerance Pingo-de-Ouro-1,2 (CE-1019). The seeds were pre-germinated on pre-weighed "germitest" type filter paper and moistened with distilled water and maintained in a chamber under controlled conditions (temperature at $25{ }^{\circ} \mathrm{C}$ and photoperiod of 12 hours) until the emergence of the radicles. Subsequently the seeds with the emerged radicles (germinated) were transferred to $3 \mathrm{dm}^{3}$ filled with sand, humus and vermiculite (6:3:1), previously irrigated, to field capacity (CC). The plants were maintained in the $\mathrm{CC}$ with daily irrigation with distilled water and, weekly, fertigated with Hoagland nutrient solution until the imposition of the water deficit that occurred at 32 days after seeding (DAS).

The treatments were applied when the plants reached the V4 stage (pre-flowering) and consisted of three water regimes: Irrigated (absence of water stress); moderate water deficit (5 days of stress, having an irrigation with $100 \mathrm{~mL}$ on the third day); and severe water deficit ( 5 consecutive days of water stress), following the completely randomized design (DIC), in a $3 \times 3$ factorial arrangement ( 3 varieties $\times 3$ water regimes) with 5 repetitions. The evaluations were performed after 5 days of the beginning of the irrigation suspension using the third and fourth trefoil fully expanded for the physiological and biochemical evaluations. For the biochemical analyzes, the leaves were collected and frozen in liquid $\mathrm{N}_{2}$, lyophilized and macerated for later use. 


\subsection{Potential Leaf Water and Biometric Parameters}

The leaf water potential was measured in the morning (05:00 a.m.-06:00 a.m.) using the fourth trefoil with the aid of a Scholander type pressure pump.

The following biometric parameters were measured: plant height using a ruler graduated in cm; number of leaves by direct counting; leaf area with the aid of an area integrator (LI-3100, Li-COR, Inc., Lincoln, NE, USA); and the dry mass of leaves using a forced air circulation greenhouse at $60^{\circ} \mathrm{C}$ for 72 hours and analytical balance.

\subsection{Gas Exchange, Chlorophyll a Fluorescence}

The gas exchange measurements were performed between 08:00 and 11:00 am on the central leaflet of the third sheet completely expanded in all plants using an infrared gas analyzer (IRGA, model LI-6400XT, LI-COR, Lincon, Nebraska, USA). Liquid photosynthesis $(A)$, stomatal conductance $\left(g_{\mathrm{s}}\right)$, transpiration rate $(E)$, ratio between internal concentration and $\mathrm{CO}_{2}$ environment $(\mathrm{Ci} / \mathrm{Ca})$ were evaluated. For these parameters, the photosynthetically active radiation (PAR) constant of $1200 \mu \mathrm{mol}$ photons $\mathrm{m}^{-2} \mathrm{~s}^{-1}$, constant concentration of $\mathrm{CO}_{2}$ (400 ppm), temperature and ambient humidity.

The chlorophyll a fluorescence was performed using the fluorometer coupled to IRGA (6400-40, LI-COR, USA) on the same sheet in which the gas exchanges were evaluated. The plants were acclimatized in the dark for 30 minutes, obtaining the minimum fluorescence parameters $(\mathrm{Fo})$ and after a pulse of saturating light, the maximum fluorescence (Fm) was obtained. Then, the potential photochemical efficiency of PSII, expressed by the Fv/Fm ratio, was calculated. Then, the potential photochemical efficiency of PSII, expressed by the Fv/Fm ratio, was calculated. With the fluorescence parameters collected in the clear (at the same moment of determination of the gas exchanges) were determined the effective quantum yield of FSII ( $\phi F S I I)$, electron transport rate (ETR), photochemical quenching (qP), non-photochemical quenching $(\mathrm{qN})$ and the non-photochemical extinction coefficient (NPQ).

\subsection{Photosynthetic Pigments}

For the determination of photosynthetic pigments (chlorophyll $a, b$, total and carotenoids), leaf discs were immersed in dimethylsulfoxide solution (DMSO) saturated with $\mathrm{CaCO}_{3}$ being kept in the dark at room temperature until quantification. The absorbances of the extracts were measured in a UV/visible spectrophotometer at wavelengths 480,649 and $665 \mathrm{~nm}$, and the concentrations were calculated using equations based on the specific absorption coefficients, according to Wellburn (1994).

\subsection{Soluble Carbohydrates and Starch}

The extracts for determination of soluble carbohydrates were prepared from $30 \mathrm{mg}$ of lyophilized leaves that were added to $5 \mathrm{~mL}$ of ethanol $(80 \%)$ and placed in a water bath at $75{ }^{\circ} \mathrm{C}$ for $1 \mathrm{~h}$ and then centrifuged at $3000 \times$ g at $4{ }^{\circ} \mathrm{C}$, being the supernatant collected and the extraction steps repeated $2 \times$. The total carbohydrate levels and reducing carbohydrate were quantified according to the methods proposed by Dubois (1956) and Nelson (1945), respectively. The non-reducing carbohydrates were obtained from the subtraction of the aforementioned parameters. The results were expressed as $\mu \mathrm{mol}$ of dry matter carbohydrate $\mathrm{g}^{-1}$.

The extracts for determination of carbohydrates were prepared with the precipitate remaining of ethanolic extract of soluble carbohydrates with respect to the precipitate $4 \mathrm{~mL}$ of perchloric acid (30\%) with subsequent stirring and centrifugation. The determination followed the method proposed by Hodge and Hofreiter (1962) and the concentration was expressed in $\mu \mathrm{mol}$ glucose $\mathrm{g}^{-1}$ dry matter.

\subsection{Proline Content}

The extracts for proline quantification were prepared using $20 \mathrm{mg}$ of lyophilized sheets added to $2.0 \mathrm{~mL}$ deionized water where they remained for $1 \mathrm{~h}$ with shaking every $10 \mathrm{~m}$. After centrifugation at $3,000 \times \mathrm{g}$ for 15 min, the supernatant was collected for quantification. The quantification was determined according to Bates et al. (1973) and the result expressed in $\mu$ mol proline $\mathrm{g}^{-1}$ dry matter.

\subsection{Extraction and Antioxidant Enzyme Activity Assays}

The enzymatic extracts were prepared from $1 \mathrm{~g}$ of fresh leaf, macerated in $4 \mathrm{~mL}$ of the potassium phosphate buffer (50 mM and pH 7). From this extract, the enzymatic activities of ascorbate peroxidase (APX), guaiacol peroxidase (GPOD), catalase (CAT) and superoxide dismutase (SOD) were measured, according to the methods of Nakano and Asada (1981), Kar and Mirsha (1976), Havir and McHale (1987) and Beauchamp and Fridovich (1971), respectively. The protein contents were quantified in the same extract of the enzymatic activities, from the Coomassie Blue reagent by the method proposed by Bradford (1976), the enzymatic activities being expressed in mmol of $\mathrm{H}_{2} \mathrm{O}_{2} \min ^{-1} \mathrm{~g}^{-1}$ protein. 


\subsection{Statistical Analysis}

Data were submitted to analysis of variance ANOVA, and when significant at $\mathrm{P} \leq 0.05$, the averages of the biometric parameters were submitted to the Scott-Knott test. For the other parameters, the Tukey test was used. Statistical analyzes were performed using the Sisvar program (Ferreira, 2011) and the graphs elaborated in SigmaPlot 11.0.

\section{Results and Discussion}

\subsection{Leaf Water Potential}

The water potential in the early morning reduced in all varieties studied with the progression of the water deficit, being this reduction more pronounced in the traditional varieties under severe water deficit (Figure 1). The greatest water potential (less negative) observed in the tolerant genotype (Pingo-de-Ouro-1,2) is consistent with a higher water economy under severe water deficit, which may be related to the tolerance pattern evidenced by this variety (Rivas et al., 2016). Strategies to mitigate the effects of the reduction of the water potential (Horie et al., 2011; Rivas et al., 2016), stomatal closure and osmotic adjustment (Farooq et al., 2011; Goufo et al., 2017).

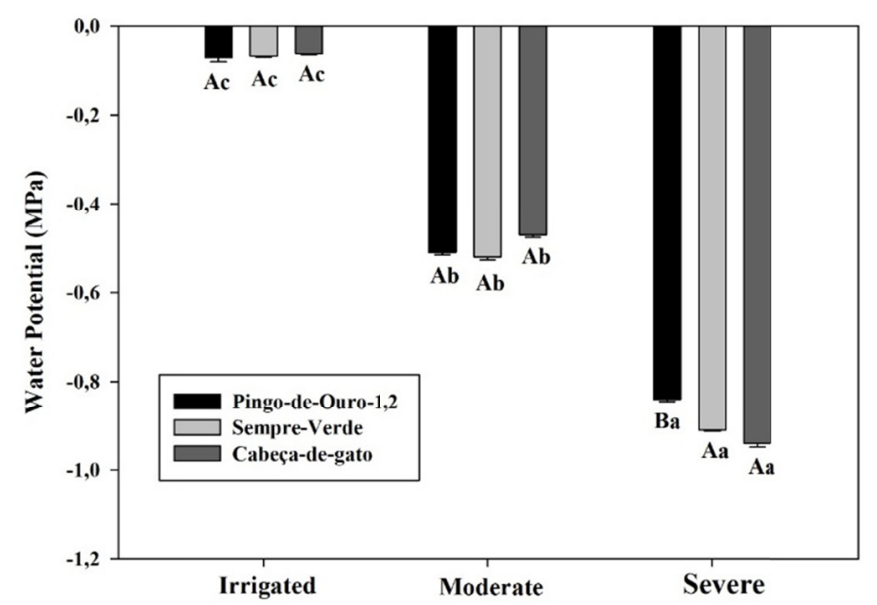

Figure 1. Leaf water potential in the morning in varieties of cowpea in the water regimes: irrigated, moderate deficit and severe deficit. The bars indicate the default error. Averages followed by distinct capital letters differ statistically between varieties within the same treatment, and distinct lowercase letters differ within the same variety at different water regimes (Tukey, $\mathrm{p}<0.05$ )

\subsection{Biometric Parameters}

For the height of the plants was not significant difference observed between the genotypes and in the water regimes studied (Figure 2A). However, the number of leaves (NF), leaf area (LA) and leaf dry mass (LDM) interacted significantly among genotypes and water regimes (Figures 2B, 2C and 2D). The Cabeça-de-Gato and Pingo-de-Ouro-1,2 genotypes presented lower NF and LA in the severe deficit (Figures 2B and 2C). The tolerant genotype maintained constant the NF and LA independent of the presence or absence of stress, presenting the lowest values when compared to the Sempre-Verde varieties in the severe deficit (Figures 2B and 2C). Studies performed by Hadi, Hussain, and Arif (2012), and Freitas et al. (2017) evaluating cowpea genotypes also observed a reduction in AF, being this a common characteristic in some genotypes. This modulation can be considered a mechanism of escape to desiccation, once the reduction of the transpiratory area keeps the water status higher for a longer time. The soil water scarcity affects the plant growth by reducing cell turgor and in extreme situations promotes foliar abscission (Slama et al., 2006). It is interesting to note that the Sempre-verde genotype did not show variation in LA or NF, however, there was greater accumulation of biomass, probably due to the higher LA that it presented, this led to present significant differences to the Cabeça-de-Gato, genotype, which reduced the biomass in the presence of water deficit (Figure 2D). Khater et al. (2018) emphasize that LA and LDM evaluation are biometric parameters indicated for the evaluation of water stress by drought in cowpea plants. Possibly the Cabeça-de-Gato destined the sugars as reserve in the form of starch (Figure 6D) for future supply. In general, the behavior of genotypes in significantly reducing its growth parameters is related to another defense mechanism, in the face of water stress. However, it is worth mentioning that the standard tolerance 
genotype Pingo-de-Ouro-1,2, managed to maintain a good performance, in front of the two regimes of water scarcity, keeping its growth indifferent to the control treatment.

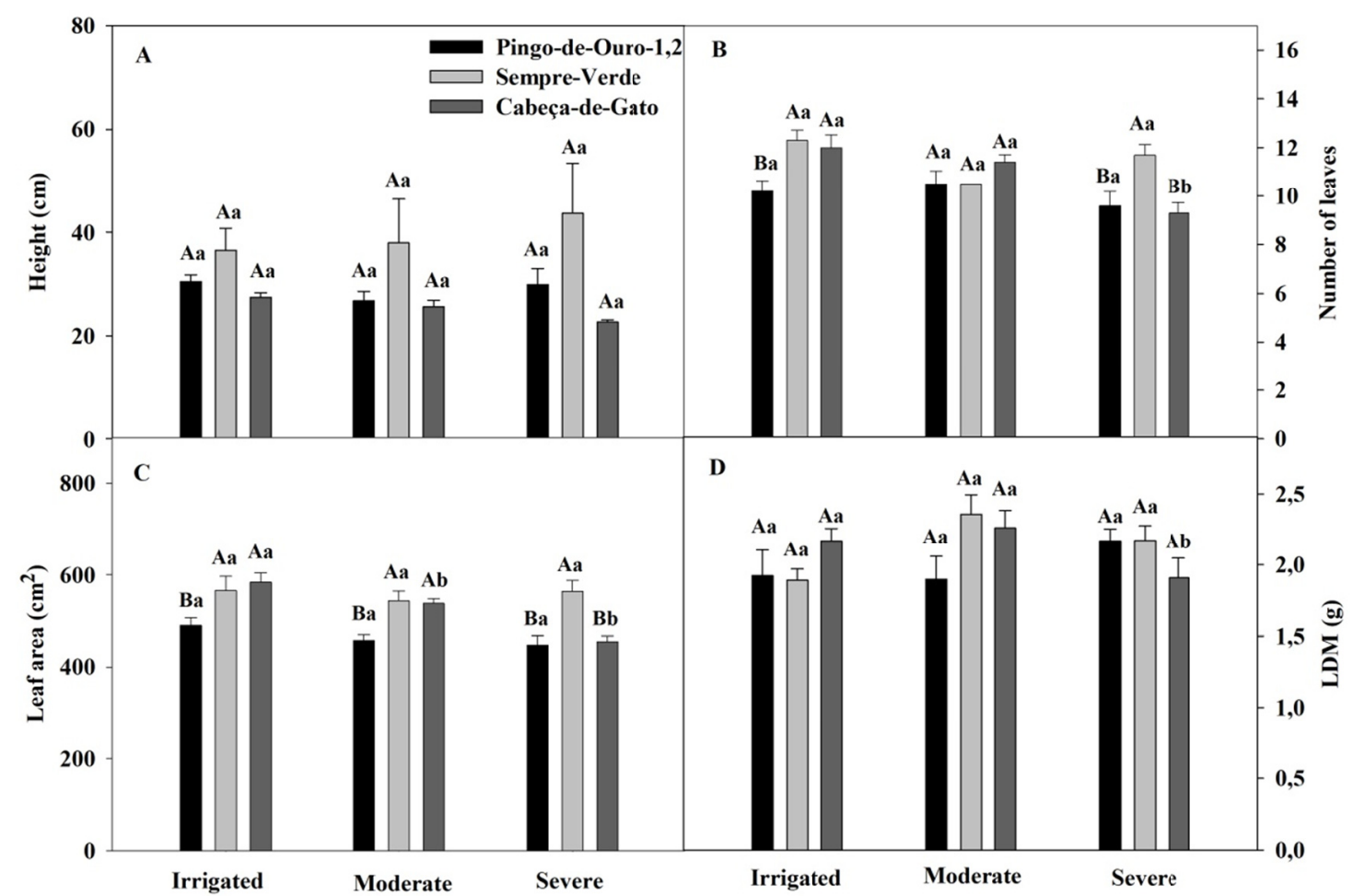

Figure 2. Influence of plant height deficit (A), number of leaves (B), leaf area (C) and leaf dry matter (D) in the varieties of cowpea in water regimes: irrigated, moderate deficit and Severe deficit. Averages followed by distinct capital letters differ statistically between the varieties within the same treatment, and distinct lowercase letters differ within the same variety at different water regimes (Scott-Knott, $\mathrm{p}<0.05$ )

\subsection{Photosynthetic Pigments}

In the absence of stress, the chlorophyll $a$ was lower only in the traditional Cabeça-de-Gato variety, and under stress conditions, there was only a reduction in chlorophyll $a$ in the two traditional varieties in the moderate deficit (Figure 3A). The genotype Pingo-de-Ouro-1,2 did not present significant difference in the levels of photosynthetic pigments in function of water deficit (Figures 3A-3D). However, the traditional varieties presented a modulation in the chlorophyll content, whereas in the Cabeça-de-Gato there was an increase of chlorophyll $a$ and $b$ in function of water stress (Figures 3A and 3B), in the Sempre-Verde there was only reduction in chlorophyll $a$ in the conditions of stress (Figure 3A).

Chlorophyll $a$ is a pigment linked to the photochemical phase, while chlorophyll $b$ functions as an accessory pigment transferring energy to the reaction centers (Kume et al., 2018). Both dry matter and chlorophyll content (Chl) are important parameters for the evaluation of tolerance to water stress in plants (Xu et al., 2013). The decrease in chlorophyll content is a consequence of drought, negatively affecting photosynthesis (Silva et al., 2014). However, the increase in the $a$ and $b \mathrm{Chl}$ levels in the Cabeça-de-Gato can be justified by the reduction of leaf area and total dry mass (Figures 2C and 2D) or the capacity of the genotype to increase levels as a response to stress (Perdomo et al., 2017), being the fall in the photosynthesis possibly consequence of the biochemical limitation.

The carotenoids act in the absorption and light transfer, besides the chlorophyll protection against the photoxidation (Havaux et al., 2014). In this study were not observed significant differences neither between the varieties nor in the different water regimes, which may be related to the NPQ having remained stable (Figure 5). 


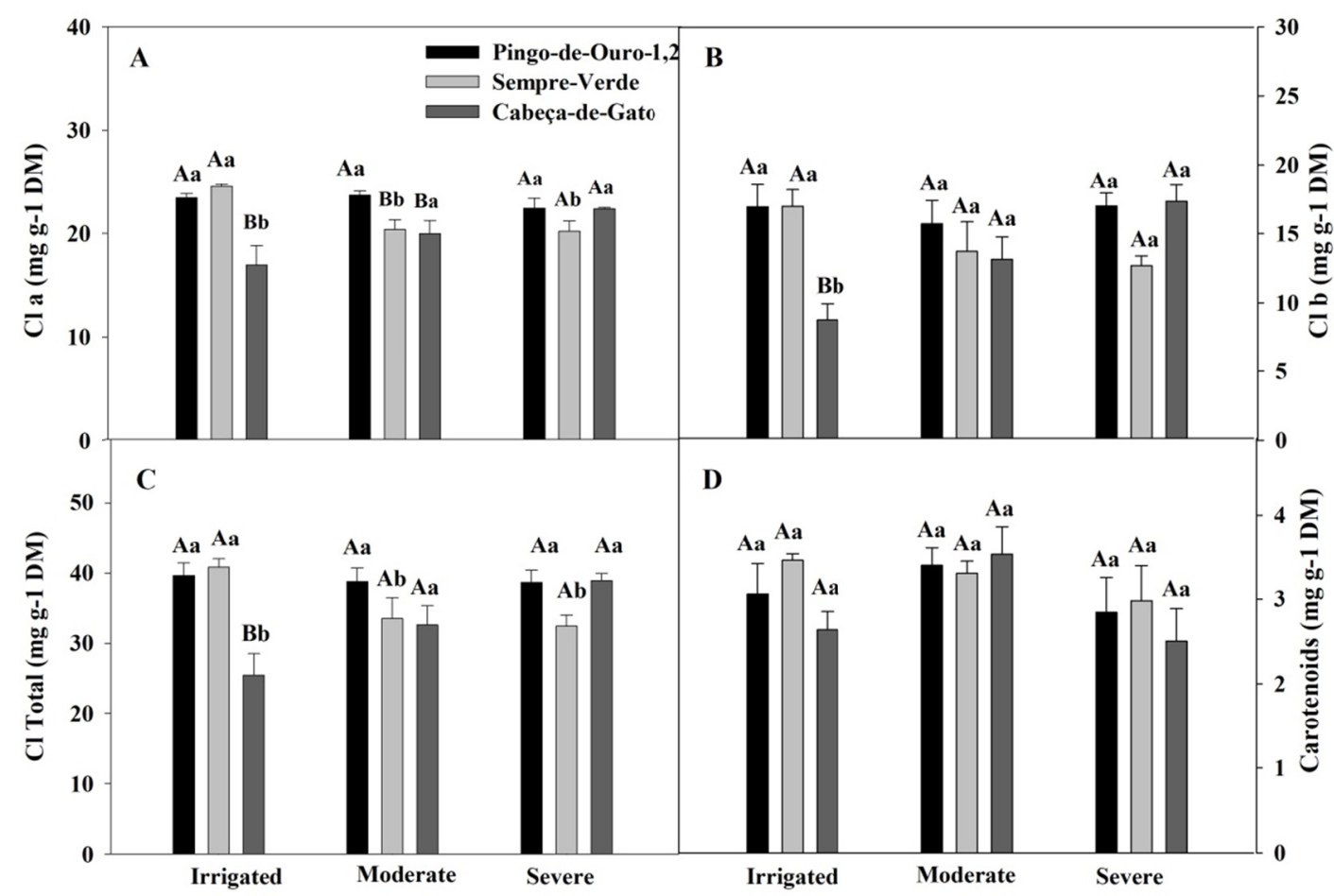

Figure 3. Influence of water deficit on the accumulation of photosynthetic pigments: chlorophyll $a$ (A), chlorophyll $b$ (B), total chlorophyll (C) and carotenoids (D) in varieties of cowpea in water regimes: irrigated, moderate deficit and severe deficit, and carotenoids in the Pingo-de-Ouro-1,2 genotypes; Sempre-verde and Cabeça-de-Gato. Statistical details described in Figure 1

\subsection{Effect of Water Stress on Gas Exchange and Chlorophyll Fluorescence a.}

The decrease of $A$ in all genotypes (Figure 4A), shows a clear relationship with soil water content, decreasing as stress becomes more pronounced. The limitation in photosynthesis may be a consequence of the reduction of $g s$ (Silva et al., 2012) that limits transpiration as a form of water economy (Sikder et al., 2015), being a defense strategy the water restriction in semi-arid regions (Condon et al., 2004), because it will reduce the loss of water to the atmosphere. However, the $\mathrm{CO}_{2}$ supply, the main substrate of photosynthesis, is reduced, causing stomatal limitation (Cunniff, Charles, Jones, Colin, \& Osborne, 2016). The reduction of $g s$ is among the first responses of plants to water stress (Munjonji et al., 2017), being this a good indication of bean crops (Medrano et al., 2004).

The limitation of photosynthesis may be diffusional, when limited only by the entry of $\mathrm{CO}_{2}$ into the mesophyll and at the carboxylation sites (Singh \& Reddy, 2011), as observed in the Pingo-de-Ouro-1,2 genotype (Figure 4B), or may be biochemical when the limitation goes beyond diffusion, with limitation in phosphorylation, Rubisco regeneration and Rubisco activase (Singh \& Reddy, 2011), as observed by the traditional genotypes by the high $\mathrm{Ci} / \mathrm{Ca}$ ratio (Figure $4 \mathrm{C}$ ), where the Sempre-Verde presented lower values for both physiological mechanisms with lower levels of $\mathrm{Chl} a$ and biochemicals being more affected by drought.

Plants under water stress can present photoinhibitory damage, however, were not observed differences in the maximum quantum efficiency parameter $(\mathrm{Fv} / \mathrm{Fm})$ in the present study, indicating that the plants had no significant commitment in the photochemical apparatus. According to Tezara et al. (2005), differences are not observed in this parameter in an experiment in a greenhouse. This fact is sustained when we observe that here was no significant increase in non-photochemical quenching (NPQ), once this mechanism is used as a PSII protector because it dissipates energy in the form of heat, thus avoiding ERO's formation (Ashraf \& Harris, 2013). There is a strong relationship between gas exchange and fluorescence parameters when comparing $A$ with ETR and qP (Graph 5). The reduction of photosynthesis is linked to the decline of qP, thus concluding that the decline in $\mathrm{NAPD}^{+}$reduction capacity acts as a protection to the photosynthetic apparatus. Therefore, it can be related that the lower photosynthesis rate in the Sempre-Verde genotype is also a consequence of a lower qP, translated into a lower ETR. 


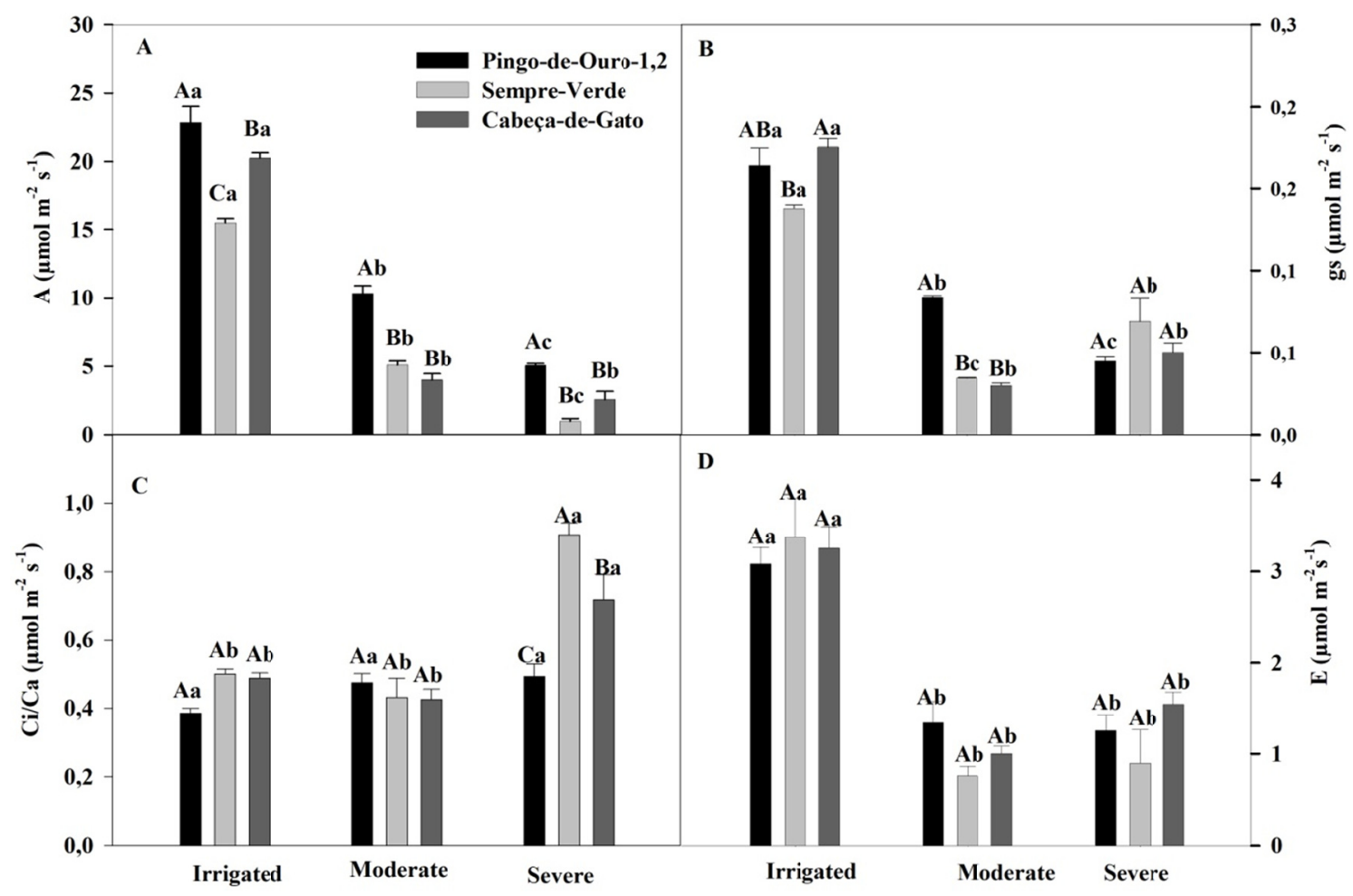

Figure 4. Influence of water deficit on photosynthesis (A), stomatal conductance (B), ratio Ci/Ca (D), transpiration (C) of the Pingo-de-Ouro-1,2, Sempre-Verde and Cabeça-de-Gato genotypes. Statistical details described in Figure 1

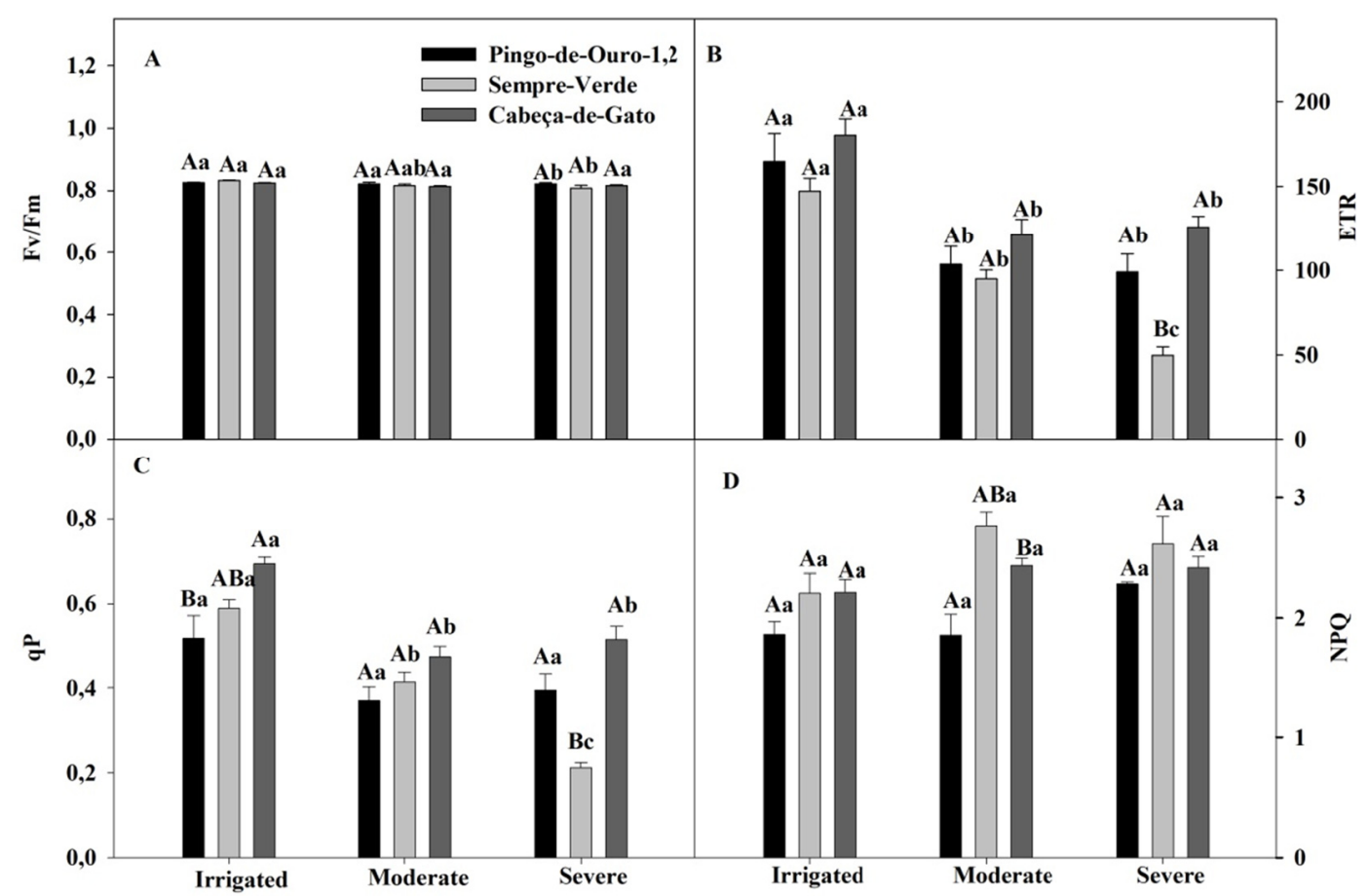

Figure 5. Influence of water deficit on potential PSII (A), electron transport rate (ETR) (B), quenching-photochemical (qp) (C), non-photochemical dissipation in the dark (NQP) (D) of the genotypes Pingo-de-Ouro-1,2, Sempre-Verde and Gato-de-Gato. Statistical details described in Figure 1 


\subsection{Osmotic Adjustment}

The osmotic adjustment, represented by the increase in the concentration of compatible solutes, is a mechanism associated with water stress (Pandey et al., 2017). Studies conducted by Lobato (2008) showed the increase in proline content, which can be observed by the present study in the two traditional varieties (Figure 7). The Pingo-de-Ouro-1,2 genotype did not show an increase in this solute, either due to the stress intensity or because it is characteristic of the genotype itself, or still, possibly for presenting other mechanisms of tolerance (Unyayar, Keles, \& Unal, 2004). According to Goufu (2017), proline acts in the NADH reduction and avoids the generation of singlet oxygen and allows dehydrated plant cells to resist dehydration, maintaining turgor (Ferreira, 2002; Zegaoui et al., 2017).

The carbohydrates (Figure 6) are also accumulated in plants that show water stress tolerance (Ebtedaie \& Shekafandeh, 2016), and their accumulation dependent on the degree of dehydration and the consequence of the degradation of starch (Tsoata, Njock, Youmbi, \& Nwaga, 2015), directly affecting water potential (Figure 1). In addition, according to Issifu et al. (2019), the accumulation of starch (Figure 6D) may signify a survival strategy, because it ensures an energetic supply for the respiration, as observed by Cabeça-de-Gato, that with imposition of the continuous deficit increases the reserve accumulation. In this way, the lowest accumulation of starch by the Pingo-de-Ouro-1,2 and Sempre-Verde can reflect on long-term damage from carbon starvation.

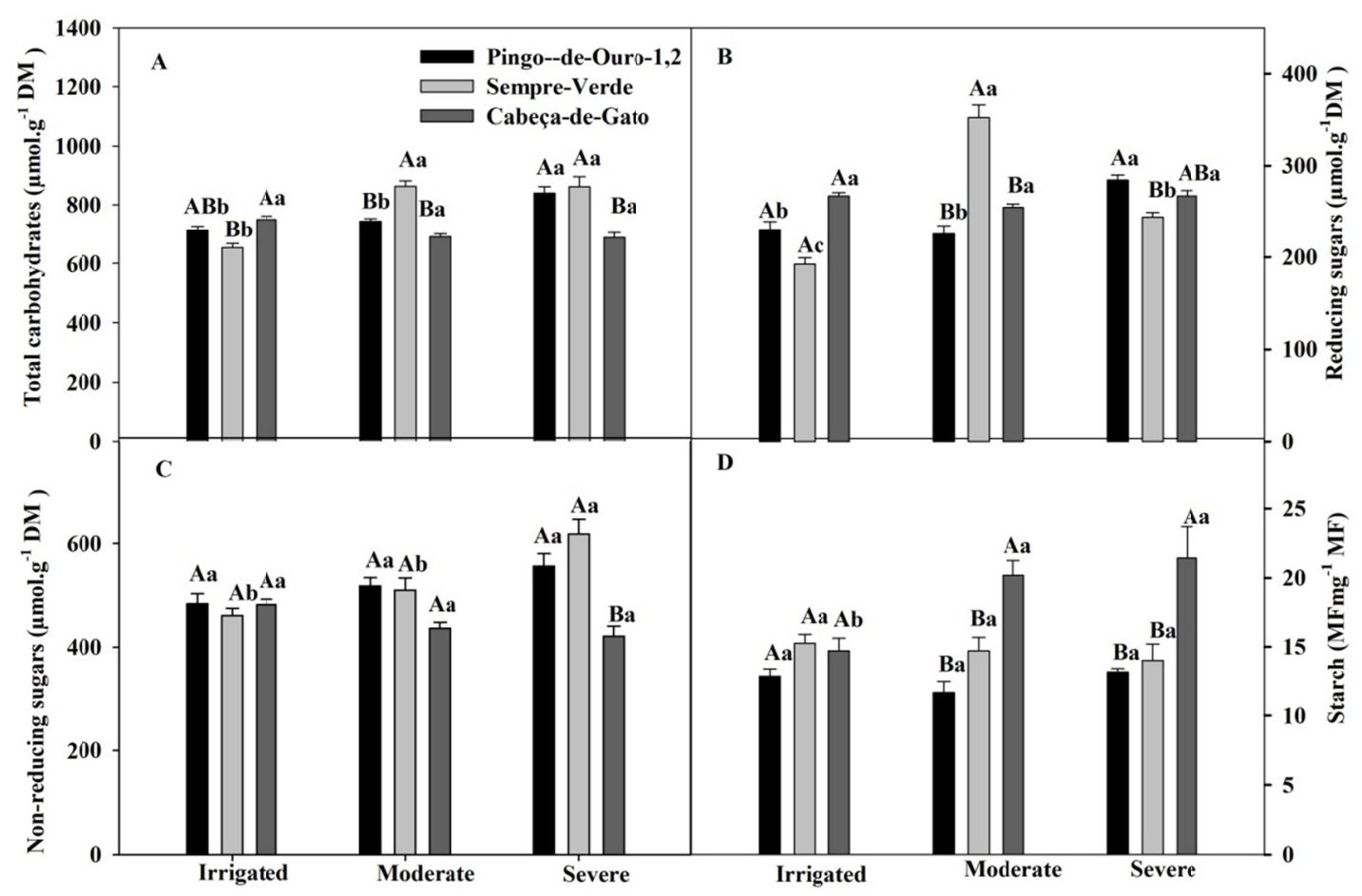

Figure 6. Influence of water deficit on total carbohydrate contents, reducing, non-reducing, and starch grains of the Pingo-de-Ouro-1,2 genotypes, Sempre-verde and Cabeça-de-Gato. Statistical details as described in Figure 1 


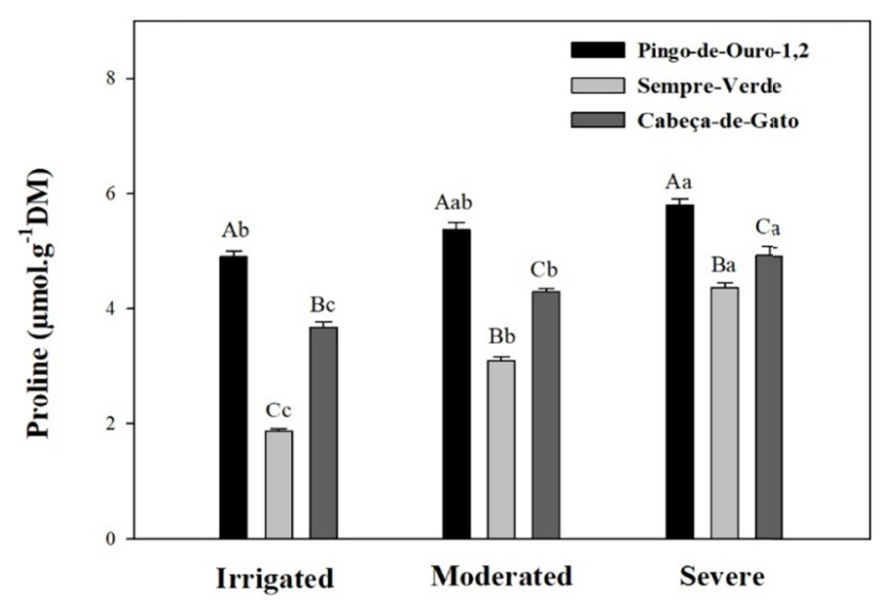

Figure 7. Influence of the water deficit on the concentration of proline in the genotypes Pingo-de-Ouro-1,2, Sempre-Verde and Cabeça-de-Gato. Statistical details as described in Figure 1. Statistical details as described in Figure 1

\subsection{Antioxidant Enzymes}

Plants subjected to abiotic stress present an excessive production of reactive oxygen species (ERO's). As a defense mechanism, the plants have an enzymatic system to prevent ERO's from causing severe damage in lipids, proteins, carbohydrates and DNA, resulting in oxidative stress (Sadeghipour, 2015). The SOD participates as the first line of defense (Apel \& Hirt, 2004; Jing, Zhou, \& Zhu, 2016) functioning as trigger for the action of other enzymes (CAT, and APX), once it acts by increasing $\mathrm{H}_{2} \mathrm{O}_{2}$ levels (Pereira et al., 2012). The APX and CAT are the two main enzymes involved in the removal of ROS (Sharma et al., 2012), being the last one, that presents the highest activity rate (Sadeghipour, 2015).

The genotypes presented increase in the activity of the enzymes, with emphasis on the G-POD enzyme (Figure 8B) in the Pingo-de-Ouro-1,2 and CAT (Figure 8C) in the Sempre-Verde. For the latter, it is observed that the high activity of this enzyme with the decrease of the photosynthesis at the biochemical level, denotes a high level of oxidative stress. While CAT levels have remained constant in the Cabeça-de-Gato, it may denote a lack of sensitivity of this parameter or the stress level was not enough to increase the activity. It can be observed that there was a great increase in the enzymes of Sempre-Verde, but they were not translated into protection of the photosynthetic apparatus, showing clear damages in the photosynthetic parameters. 


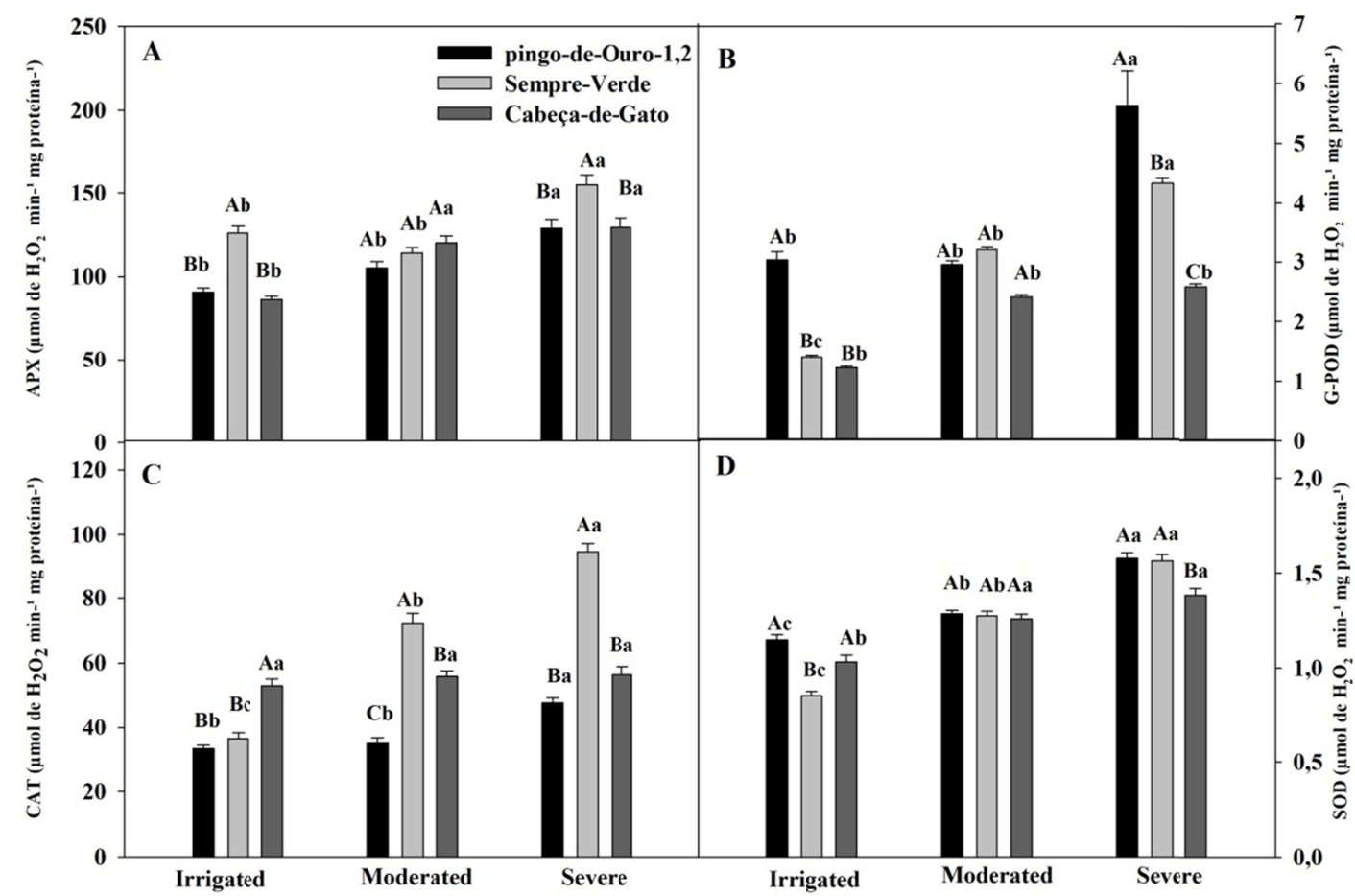

Figure 8. Antioxidative activities of the ascorbate peroxidase (APX), guaiacol peroxidase (G-POD), catalase (CAT) superoxide dismutase (SOD) genotypes of Pingo-de-Ouro-1,2, Sempre-Verde and Cabeça-de-Gato (I), moderate stress (M) and severe stress (S). Statistical details as described in Figure 1

\section{Conclusion}

The water stress affects negatively the genotypes of cowpea, with alterations in both morphological and physiological levels and each genotype respond differently to drought. The Pingo-de-Ouro-1,2 genotype confirmed its tolerance pattern, presenting higher photosynthetic rates, total carbohydrate accumulation and high proline content, being this parameter invariable for this genotype. Among the tested local varieties, the Cabeça-de-Gato stood out because of the higher rates of photosynthesis, ETR and proline accumulation in relation to Sempre-Verde.

\section{References}

Alderfasi, A. A., Alzarqaa, A. A., AL-Yahya, F. A., Roushdy, S. S., Dawabah, A. A., \& Alhammad, B. A. (2017) Effect of combined biotic and abiotic stress on some physiological aspects and antioxidant enzymatic activity in mungbean (Vigna radiate L.). Africa. Journal of Agriculture Research, 12(9), 700-705. https://doi.org/10.5897/AJAR2016.12084

Apel, K., \& Hirt, H. (2004). Reactive oxygen species: Metabolism, oxidative stress, and signal transduction. Annu Review Plant Biology, 55, 373-399. https://doi.org/10.1146/annurev.arplant.55.031903.141701

Araus, J. L., Slafer, G. A., Reynolds, M. P., \& Royo, C. (2002). Plant breeding and drought in C3 cereals: What should we breed for? Annals of Botany, 89, 925-940. https://doi.org/10.1093/aob/mcf049

Ashraf, M., \& Harris, P. J. C. (2013). Photosynthesis under stressful environments: An overview. Photosynthetica, 51(2), 163-190. https://doi.org/10.1007/s11099-013-0021-6

Blum, A. (2016). Osmotic adjustment is a prime drought stress adptive engine in support of plant production. Plant, Cell and Environment, 40, 4-10. https://doi.org/10.1111/pce.12800

Carvalho, M. H. C. (2008). Drought stress and reactive oxygen species. Plant Signaling and Behavior, 3, 156-165. https://doi.org/10.4161/psb.3.3.5536

Cardona-Ayala, C., Jarma-Orozco, A., \& Araméndiz-Tatis, H. (2013). Drought adaptation mechanisms in the cowpea (Vigna unguiculata (L.) Walp.). A review. Revista Colombiana de Ciencias Hortícolas, 7(2), 277-288. https://doi.org/10.17584/rcch.2013v7i2.2242 
Cecchini, N. M., Monteoliva, M. I., \& Alvarez, M. E. (2011). Proline dehydrogenase is a positive regulator of cell death in different kingdoms. Plant Signaling \& Behavior, 6(8), 1195-1197. https://doi.org/10.4161/ psb.6.8.15791

Condon, A. G., Richards, R. A., Rebetzke, G. J., \& Farquhar, G. D. (2004). Breeding for high water-use efficiency. Journal of Experimental Botany, 55(407), 2447-2460. https://doi.org/10.1093/jxb/erh277

Costa, R. C. L., Lobato, A. K. S., Silveira J. A. G., \& Laughinghouse, H. D. (2011). ABA-mediated proline synthesis in cowpea leaves exposed to water deficiency and rehydration. Turkish Journal of Agriculture and Forestry, 35, 309-317.

Costa, A. C., Rezende-Silva S. L., Megguer, C. A., Moura, L. M. F., Rosa M., \& Silva, A. A. (2015). The effect of irradiance and water restriction on photosynthesis in young jatobá-do-cerrado (Hymenaea stigonocarpa) plants. Photosynthetica, 53, 118-127. https://doi.org/10.1007/s11099-015-0085-6

Cunniff, J., Charles, M., Jones, G., \& Osborne, C. P. (2016). Reduced plant water status under sub-ambient pCO $_{2}$ limits plant productivity in the wild progenitors of C3and C4cereals. Annals of Botany, 118(6), 1163-1173. https://doi.org/10.1093/aob/mcw165

Dubois, M., Gillies, K. A., Hamilton, J. K., Rebers, P. A., \& Smith, F. (1956) Colorimetric method for determination of sugars and related substances. Analytical Chemistry, 28, 350-356. https://doi.org/10.1021/ ac60111a017

Ebtedaie, M., \& Shekafandeh. A. (2016) Antioxidant and carbohydrate changes of two pomegranate cultivars under deficit irrigation stress. Spanish Journal Agricultural Research, 14(4), 1-9. https://doi.org/10.5424/ sjar/2016144-9317

Efeoğlu, B., Ekmekçi, Y., \& Çiçek, N. (2008). Physiological responses of three maize genótipos to drought stress and recovery. South African Journal of Botany, 75, 34-42. https://doi.org/10.1016/j.sajb.2008.06.005

Farooq, M., Wahid, A., Kobayashi, N., Fujita, D., \& Basra, S. M. A. (2009). Plant drought stress: Effects, mechanisms and management. Agronomy for Sustainable Development, 29, 185-212. https://doi.org/ 10.1051/agro:2008021

Gagné-Bourque, F., Bertrand, A., Claessens, A., Aliferis, K. A., \& Jabaji, S. (2016). Alleviation of drought stress and metabolic changes in timothy (Phleum pretense L.) colonized with Bacillus subtilis B26. Frontiers in Plant Science, 7, 584. https://doi.org/10.3389/fpls.2016.00584

Goufo, P., Moutinho-Pereira, J. M., Jorge, T. F., Correia, T. M., Oliveira, M. R., Rosa, E. A. S., ... Trindade, H. (2017). Cowpea (Vigna unguiculata L. Walp.) Metabolomics: Osmoprotection as a Physiological Strategy for Drought Stress Resistance and Improved Yield. Frontiers in Plant Science, 8, 1-22. https://doi.org/ $10.3389 /$ fpls.2017.00586

Hadi, F., Hussain, F., \& Arif, M. (2012). Effect of different water treatments on growth behaviour of Cowpea (Vigna unguiculata subsp. Unguiculata (L.) Walp.) Journal of Scientific Research and Reviews, 1(1), 1-6.

Hamidou, F., Zombre, G., \& Braconnier, S. (2007). Physiological and biochemical responses of cowpea genotypes to water stress under glasshouse and field conditions. Journal of Agronomy and Crop Science, 193(4), 229-237. https://doi.org/10.1111/j.1439-037X.2007.00253.x

Havaux, M. (2014). Carotenoid oxidation products as stress signals in plants. The Plant Journal, 79(4), $597-606$. https://doi.org/10.1111/tpj.12386

Havir, E. A., \& McHale, N. A. (1987). Biochemical and Developmental Characterization of Multiple Forms of Catalase in Tobacco Leaves. Plant Physiology, 84, 450-455. https://doi.org/10.1104/pp.84.2.450

Hodge, J. E., \& Hofreiter, B. T. (1962). Determination of reducing sugars and carbohydrates. In R. L. Whistler, \& M. L. Wolfrom (Eds.), Methods in Carbohydrate Chemistry (pp. 380-394). Academic Press, New York.

Horie, T., Kaneko, G., Sugimoto, S., Sasano, S. K., Panda, M., \& Katsuhara, M. (2011). Mechanisms of water transport mediated by pip aquaporins and their regulation via phosphorylation events under salinity stress in barley roots. Plant Cell Physiology, 52, 663-675. https://doi.org/10.1093/pcp/pcr027

Issifu, H., Ametsitsi, G. K., De Vries, L. J., Djagbletey, G. D., Adu-Bredu, S., Vergeer, P., \& Veenendaal, E. (2019). Variation in vegetation cover and seedling performance of tree species in a forest-savanna ecotone. Journal of Tropical Ecology, 1-9. https://doi.org/10.1017/S0266467418000469 
Jing, G., Zhou, J., \& Zhu, S. (2016). Effects of nitric oxide on mitochondrial oxidative defence in postharvest peach fruits. Science of Food and Agriculture, 96, 1997-2003. https://doi.org/10.1002/jsfa.7310

Khater, M. A., Dawood, M. G., Sadak, M. S., Shalaby, M. A., El-Awadi, M. E., \& El-Din, K. G. (2018). Enhancement the performance of cowpea plants grown under drought conditions via trehalose application. Middle East J, 7(3), 782-800.

Kume, A., Akitsu, T., \& Nasahara, K. N. (2018). Why is chlorophyll b only used in light-harvesting systems? Journal of Plant Research, 131(6), 961-972. https://doi.org/10.1007/s10265-018-1052-7

Lobato, A. K. S., Oliveira Neto, C. F., Costa, R. C. L., Santos Filho, B. G., Cruz, F. J. R., \& Laughinghouse, I. V. H. D. (2008). Biochemical and physiological behavior of Vigna unguiculata (L.) Walp. under water stress during the vegetative phase. Asian Jounal Plant Science, 7, 44-49. https://doi.org/10.3923/ajps.2008.44.49

Medrano, H., Escalona, J. M., Bota, J., Gulias, J., \& Flexas, J. (2002). Regulation of photosynthesis of C3 plants in response to progressive drought: Stomatal conductance as a reference parameter. Annals of Botany, 89, 895-905. https://doi.org/10.1093/aob/mcf079

Morengo, J. A., Torres, R. R., \& Alves, M. L. (2017). Drought in Northeast Brazil—Past, present, and future. Theoretical and Applied Climatology, 129, 1189-2000. https://doi.org/10.1007/s00704-016-1840-8

Munjonji, L., Ayisi, K., Boeckx, P., \& Haesaert, G. (2018). Stomatal behavior of cowpea genotypes grown under varying moisture levels. Sustainability, 10(1), 12.

Nakano, Y., \& Asada, K. (1981). Hydrogen Peroxide Is Scavenged by Ascorbate-Specific Peroxidase in Spinach Chloroplasts. Plant Cell Physiology, 22, 1068-1072. https://doi.org/10.1093/oxfordjournals.pcp.a076232

Nelson, N. A. (1944). A photometric adaptation of the Somogyi method for the determination of glucose. Journal of Biology Chemistry, 153, 375-380.

Pandey, B. R., Burton, W. A., Salisbury, P. A., \& Nicolas, M. E. (2017). Comparison of osmotic adjustment, leaf proline concentration, canopy temperature and root depth for yield of juncea canola under terminal drought. Journal of Agronomy and Crop Science, 203(5), 397-405. https://doi.org/10.1111/jac.12207

Perdomo, J. A., Capó-Bauçà, S., Carmo-Silva, E., \& Galmés, J. (2017). Rubisco and rubisco activase play an important role in the biochemical limitations of photosynthesis in rice, wheat, and maize under high temperature and water deficit. Frontiers in Plant Science, 8, 490. https://doi.org/10.3389/fpls.2017.00490

Rebouças, D. M., Sousa, Y. M., Bagard, M., Costa, J. H., Jolivet, Y., Melo, D. F., \& Repellin A. (2017) Combined Effects of Ozone and Drought on the Physiology and Membrane Lipids of Two Cowpea (Vigna unguiculata (L.) Walp) Cultivars, Plants, 6(3), 270-275. https://doi.org/10.3390/plants6010014

Rivas, R., Falcão, H. M., Ribeiro, R. V., Machado, E. C., Pimentel, C., \& Santos, M. G. (2016). Drought tolerance in cowpea species is driven by less sensitivity of leaf gas exchange to water deficit and rapid recovery of photosynthesis after rehydration. South African Journal of Botany, 103, 101-107. https://doi.org/10.1016/j.sajb.2015.08.008

Rocha, M. M., Carvalho, K. J. M., Freire Filho, F. R., Lopes, A. C. A., Gomes, R. L. F., \& Sousa, I. S. (2009). Controle genético do comprimento do pedúnculo em feijão-caupi. Pesquisa Agropecuária Brasileira, 44(3), 270-275. https://doi.org/10.1590/S0100-204X2009000300008

Sadeghipour, O. (2015). Alleviation of lead toxicity by nitric oxide in cowpea (Vigna unguiculata L. Walp). International Journal of Biosciences, 6(7), 58-56. https://doi.org/10.12692/ijb/6.7.58-65

Sicher, R. C., Timlin, D., \& Bailey, B. (2012). Responses of growth and primary metabolism of water-stressed barley roots to rehydration. J. Plant Physiol., 169(7), 686-95. https://doi.org/10.1016/j.jplph.2012.01.002

Sikder, S., Foulkes, J., West, H., De Silva, J., Gaju, O., Greenland, A., \& Howell, P. (2015). Evaluation of photosynthetic potential of wheat genotypes under drought condition. Photosynthetica, 53(1), 47-54. https://doi.org/10.1007/s11099-015-0082-9

Simova-Stoilova, L. P., Romero-Rodríguez, M. C., Sánchez-Lucas, R., Navarro-Cerrillo, R. M., Medina-Aunon, J. A., \& Jorrín-Novo, J. V. (2015). 2-DE proteomics analysis of drought treated seedlings of Quercus ilex supports a root active strategy for metabolic adaptation in response to water shortage. Frontiers in Plant Science, 6(8), 1-16. https://doi.org/10.3389/fpls.2015.00627 
Singh, S. K., \& Reddy, K. R. (2011). Regulation of photosynthesis, fluorescence, stomatal conductance and water-use efficiency of cowpea (Vigna unguiculata [L.] Walp.) under drought. Journal of photochemistry and photobiology. B: Biol, 105, 40-50. https://doi.org/10.1016/j.jphotobiol.2011.07.001

Slama, I., Messedi, D., Ghunaya, T., Savaure, A., \& Abdelly, C. (2006). Effects of water deficit on growth and proline metabolism in Sesuvium portulacastrum. Environmental and Experimental Botany, 56, 231-238. https://doi.org/10.1016/j.envexpbot.2005.02.007

Shui, X. R., Chen, Z. W., \& Li, J. X. (2013). MicroRNA prediction and its function in regulating drought-related genes in cowpea. Plant Science, 210, 25-35. https://doi.org/10.1016/j.plantsci.2013.05.002

Tezara, W., Marín, O., Rengifo, E., Martínez, D., \& Herrera, A. (2005). Photosynthesis and photoinhibition in two xerophytic shrubs during drought. Photosynthetica, 43, 37-45. https://doi.org/10.1007/s11099-005-7045-5

Tsoata, E., Njock, S. R., Youmbi, E., \& Nwaga, D. (2015). Early effects of water stresson some biochemical and mineral parameters of mycorrhizal Vigna subterranean (L.) Verdc. (Fabaceae) cultivated in Cameroon. International Journal of Agronomy and Agricultural Research, 7(2), 21-35.

Unyayar, S., Keles, Y., \& Unal, E. (2004). Proline and ABA levels in two sunflowers genotypes subject to water stress. Bulgarian Journal of Plant Physiology, 30(3-4), 34-47. https://doi.org/10.1270/jsbbs.15068

Wellburn, A. R. (1994). The spectral determination of chlorophylls a and b, as weel as total carotenoids, using various solvents with spectrophotometers of different resolution. Journal of Plant Physiology, 144, 307-313. https://doi.org/10.1016/S0176-1617(11)81192-2

Xu, C., Li, X., \& Zhang, L. (2013). The effect of calcium chloride on growth, photosynthesis, and antioxidant responses of Zoysia japonica under drought conditions. Plos One, 8(7), 1-10. https://doi.org/10.1371/journal. pone.0068214

Xu, Z., \& Zhou, G. (2008). Responses of leaf stomatal density to water status and its relationship with photosynthesis in a grass Journal of Experimental Botany, 59(12), 3317-3325. https://doi.org/10.1093/ $\mathrm{jxb} / \mathrm{ern} 185$

\section{Copyrights}

Copyright for this article is retained by the author(s), with first publication rights granted to the journal.

This is an open-access article distributed under the terms and conditions of the Creative Commons Attribution license (http://creativecommons.org/licenses/by/4.0/). 